УдК: 323.28:623.458

DOI: https://doi.org/10.18485/fb_covid19.2020.ch5

\title{
БИОТЕРОРИЗАМ КАО БЕЗБЕДНОСНА ПРЕТЊА НАКОН КОВИДА 19: СТАРИ МИТОВИ ИЛИ НОВА ИСТИНА
}

\author{
мср Ненад Кокошков ${ }^{1}$, \\ доц. др Милован Трбојевић²
}

Апстракт: Основна идеја овог рада је да се кроз анализу актуелне пандемије ковида 19, као и претходних искустава појединих држава у области супротстављања биотероризму, дође до закључака о новим могућим облицима његовог испољавања и злоупотребе биолошких агенаса у терористичким актима. Наиме, кроз осврт на активности Ал Каиде и јапанске секте Аум Шинрикјо и студију случаја антракс писама у САД из 2001. године указано је на кључна искуства и препреке у набавци, развоју и примени биолошког оружја. Сем тога, представљена су кључна новостечена искуства и поуке из пандемије ковида 19 у домену јавног здравља, ефикасности здравствених система и глобалне безбедности. Уједно, профилисани су потенцијални будући корисници биолошког оружја, као и могуће методе примене односно мете деловања. Коначно, наглашена је одговорност стручне и академске заједнице која се бави проучавањем биотероризма на основама досадашњих склоности друштава да се безбедносни значај биотероризма и његове могуће последице по правилу преувеличавају или потцењују. Управо у том широком простору безбедносних процена, од апокалиптичних размера у људским жртвама до игнорисања ризика и могућих последица, ковид 19 нам пружа врло драгоцена искуства у објективном и правилном сагледавању неког будућег испољавања биотероризма као безбедносне претње.

Кључне речи: ковид 19, биотероризам, пандемија SARS-KoV-2, Ал Каида, Аум Шинрикјо.

\section{УВОД}

За здравствене системе држава̂ потпуно је ирелевантно да ли је пандемична болест настала као природни процес или последица деструктивног акта појединца или неке организације. Њихов задатак је да спасавају животе болесних

\footnotetext{
${ }^{1}$ Академија за националну безбедност, Београд; e-mail: kokoskov dr nenad@yahoo.com

${ }^{2}$ Академија за националну безбедност, Београд.
} 
људи и спречавају даље ширење заразе. Међутим, ако се масовно оболевање људи посматра из угла националне безбедности као могућа последица нечијег субверзивног деловања, онда она представља и тему за обавештајно-безбедносне структуре државе, при чему у први план избија биотероризам као могући узрок једног таквог догађаја.

Вероватно, најтежа консеквенца неког биотерористичког напада је пандемија, тј. глобално дистрибуирана заразна болест која би изазвала масовна оболевања људи и бројне поремећаје у здравственом, економском, културном и сваком другом сегменту функционисање друштва. Актуелна пандемија ковида 19 у том смислу представља врло убедљив и аргументован пример у којој мери глобална медицинска криза постаје геополитички, али и безбедносни проблем. На основу досадашњих искустава у спречавању ширења и отклањању последица ковида 19 можемо рећи да је већина земаља показала недовољну ефикасност националних здравствених система у смислу дефицитарности лекара, специјалистичке опреме и лекова, болничких капацитета и др.

Међутим, негативна искуства кроз која пролазимо током пандемије ковида 19 свакако испољавају одређене утицаје на све релевантне актере у домену националне и глобалне безбедности. Овде мислимо не само на субјекте унутар безбедноснообавештајних система већ и на најзначајније носиоце безбедносног угрожавања: терористичке групе и мреже, криминалне организације, припаднике екстремних организација различитих делова идеолошког спектра, али и радикализоване појединце у типу усамљених вукова. Циљ нашег рада је да укаже како је пандемија изазвана вирусом SARS-CoV-2 утицала на перцепцију биолошког оружја као потенцијалног средства деловања у будућности, односно да ли ковид 19 у новом безбедносном амбијенту реафирмише биотероризам као безбедносну претњу?

\section{БИОТЕРОРИЗАМ КАО БЕЗБЕДНОСНИ ФЕНОМЕН}

У сагледавању биотероризма као безбедносног феномена мора се имати у виду да унутар професионалне и академске заједнице постоје бројне неусаглашености и разлике у ставовима о његовом значају и перспективи. Истакнути теоретичар биотероризма М. Лајтенберг (Milton Leitenberg) предводник је академске струје која сматра да је „ризик од примене биолошког оружја од стране терориста систематично и намерно преувеличан“. Он ову тезу аргументује ситуацијом насталом након историјских искустава САД из 2001. године и предимензионираних реакција државних структура и медија на напад антраксним писмима ${ }^{3}$. Кларк (Clark William) чак иде корак даље и тврди да је готово незамисливо да је иједна терористичка организација коју познајемо

3 Milton Leitenberg „Bioterrorism Hyped“; LA Times, 17th February 2006, https://www.latimes.com/archives/la-xpm-2006-feb-17-oe-leitenberg17-story.html, $17 / 08 / 2020$. 
способна да самостално развије и примени биолошко оружје на територији САД 4 . Насупрот овим тврдњама, Сајмон (Jefrey Simon) заступа став да су технолошке, логистичке, организационе и материјалне препреке које прате израду и употребу биолошког оружја све мање, па самим тим вероватноћа примене истога расте. 5 своме образложењу Сајмон указује на бројне разлоге који би мотивисали и афирмисали употребу биолошког оружја у рукама терориста: потреба за новим и агресивнијим облицима деловања уз изазивање масовних жртава; утицај државних субјеката на превазилажењу препрека у изради и примени биолошког оружја и доступност информација, знања и људи који могу бити од користи у његовој изради. Ипак оно око чега се већина теоретичара слаже можда је најбоље формулисао Ворхар (Voorhaar Heather), који је рекао је да је биотероризам „један непредвидив, мало вероватан, али високо штетан догађај 6“.

Прагматично гледано, биотероризам је можда најбоље посматрати као специфичан појавни облик тероризма, при чему је акценат стављен на избор средства којим се делује (биолошко оружје), а не на идеолошко утемељење, циљеве или особености самих носиоца терористичких активности. Тиме се заправо избегавају бројне академске, међународноправне и политичке дискусије и неслагања које прате дефинисање самог тероризма као безбедносног феномена7. Дакле, биотероризам је терористички акт заснован на примени биолошког оружја. У овој врло суженој дефиницији биотероризма наглашава се биолошко оружје као његова главна функционална детерминанта.

Управо за својства биолошког оружја везан је и један од најпознатијих митова који га прате још из периода Хладног рата. Сада већ давне 1988. године председавајући иранског парламента Али Акбар Хашеми Расфанџани (Ali Akbar Hashemi Rasfanjani) je у обраћању иранским војним званичницима први пут употребио формулацију „атомска бомба сиромашних“, која се и данас користи као синоним за биолошко, односно хемијско оружје. Наиме, он је изјавио: „Хемијско и биолошко оружје су атомска бомба сиромашних и могу се лако произвести. Ми их морамо узети у обзир макар за нашу одбрану. Иако је примена тог оружја нехумана, рат нас је научио да је међународни закон само мртво слово на папиру.“8 Ова теза је у тадашњем безбедносном контексту доминације нуклеарног

4 William Clark, „Is the Threat of Bioterrorism Exaggerated?“, Home Land Security News, 23rd May 2008, http://www.homelandsecuritynewswire.com/threat-bioterrorism-exaggerated, $17 / 08 / 2020$.

5 Jeffrey Simon, Terrorist and Potential Use of Biological Weapons, A discussion of Possibilities, RAND Corporation, Santa Monica, 1989.

6 Heather Voorhaar, Antibody Architecture: Responding to Bioterrorism, Master Thesis, Clemnson University, Advisor David Allison, 2009, p. 1.

7 Алекс Шмид (Alex Schmidt), холандски теоретичар, проучавајући тероризам као безебедносни феномен, успео је да прикупи преко 250 различитих дефиниција тероризма. Видети: Alex Schmidt, The Routledge Handbook of Terrorism Research, Routledge, London and New York, 2011.

8 IRNA, 19. October 1998; FBIS Document, FBIS-NES, 19. October 1998; Paula Desutter, Denial and Jeopardy: Deterring Iranian Use of NBC Weapons, National Defense University, Washington D.C., 1997. 
оружја деловала логично с обзиром да биолошко оружје може имати подједнако разоран ефекат примене, узимајући у обзир критеријум броја људских жртава, али са неупоредиво мањим утрошком првенствено материјалних ресурса у односу на нуклеарно оружје.

За суштинско разумевање биотероризма као претње неопходно је упознати и основне карактеристике процеса трансформације биолошког агенса у биолошко оружје. Говорећи о есенцијалним захтевима који се морају примењивати у циљу производње биолошког оружја, Лајтенберг као један од најистакнутијих теоретичара биотероризма наводи следеће предуслове: поседовање одговарајућег соја патогеног микроорганизма, експертско знање и вештину у руковању микроорганизмима, њиховој обради, култивисању, стандардизацији, чувању и коначно ефикасној дисперзији‥ Посматрајући вепонизацију биолошког оружја крајње прагматично, Кларк наводи да је неопходно поседовати следеће ресурсе: материјална средства, стручне људе неопходне за производњу оружја (микробиолог, биохемичар, метеоролог, биоинжењер и др), али и људе који су спремни да изведу биотерористички напад ${ }^{10}$. Досадашња безбедносна пракса је показала да се у овим ресурсима и биотехнолошким процесима налазе и најзначајнија ограничења која терористичким организацијама, покретима и појединцима стоје на путу у биотерористичком деловању.

\section{ИСТОРИЈСКИ ПРЕГЛЕД БИОТЕРОРИСТИЧКИХ НАПАДА}

У краткој и срећом не тако богатој историји биотероризма морамо рећи да је међународна безбедносна заједница искусила само неколико верификованих биотерористичких напада. У овом контексту је врло илустративно и истраживање које је спровео Карус (Seth Carus), који је кроз јединствену и свеобухватну студију обухватио период од 1900-1998. године и при томе описао 180 случајева циљане злонамерне примене биолошких агенаса од стране различитих недржавних субјеката угрожавања11. Међутим, само пет (5) је квалификовано као терористички напад са успешном реализацијом и испуњеним циљевима. Позивајући се на студију Универзитета Мериленд која се бавила применом

www.ndu.edu/ndu/inss/books/dajd/ch5.html; Michael Eisenstadt, Iranian Military Power: Capabilities and Intentions, The Washington Institute for Near East Policy, Washington D.C., 1996, pp. 25-26.

9 Milton Leitenberg, Assesing the Biological Weapons and Bioterrorism Threat, Strategic Studies Institute, Carlisle, 2005, pp. 43-46.

10 William Clark, Bracing for Armagedon-The Science and Politics of Bioterrorism in America, Oxford University Press, Oxford, 2008.

11 Карус је у овој студији регистровао не само верификоване случајеве примене биолошког агенса већ и оне који су се базирали на поседовању биолошког агенса, али без његове конкретне примене, односно намери стицања биолошког агенса и коначно претњи примене биолошког агенса (изазивање страха и хаоса). Видети: W. Seth Carus, Bioterrorism and Biocrimes: The Ilicit Use of Biological Agents Since 1990, National Defence University Washington, D.C., 2001, pp. 7-8. 
хемијских, биолошких, радиолошких и нуклеарних (ХБРН) средстава у активностима недржавних актера у периоду 1996-2016. године, Акерман и Џејком (Ackerman Gary, Michelle Jacome) истичу да је за 4 године (2012-2016) било само 11 инцидената у којима су недржавни актери склони насиљу применили биолошка средства. При томе је реч о инцидентима малог обима и без значајних консеквенци ${ }^{12}$. У даљем тексту биће анализирано неколико значајних примера биотерористичких активности које су се догодиле до појаве ковида19.

Јапанска апокалиптична секта Аум Шинрикјо заузима најзначајније место у скромној историји биотероризма. Секта је широј јавности постала позната по нападу сарином у токијском метроу 1993. године, мада је мање познато да је била врло активна на производњи и примени биолошког оружја. Ову организацију је карактерисала чврста идеолошка утемељеност са доминантним харизматичним лидером на челу. На врхунцу моћи имала је преко 10.000 следбеника широм света, као и респектабилне материјалне и логистичке ресурсе. Аум је у периоду 1990-1995. године спровео неколико биотерористичких напада на различите мете у Токију, делујући применом ботулинума и антракса. Међутим, из разлога техничких недостатака у дисеминацији агенса и коришћења апатогеног соја антракса ти напади нису имали планиране ефекте и прошли су потпуно незапажено безбедносним органима. У светлу веома скромног броја биотерористичких случајева које је свет имао, пример Аум Шинрикјо данас заправо представља један непроцењен извор корисних информација безбедносним структурама које се баве превенцијом и борбом против тероризма. При томе, можда је кључни закључак да материјални ресурси, лабораторијска инфраструктура и стручни људи нису гарант успеха у биотероризму.

Ал Каида је активности на стицању биолошког оружја започела 1999. Године, прво кроз регрутовање стручњака, обезбеђивање неопходне опреме и биолошких агенаса. На челу пројекта се налазио формацијски заменик Бин Ладена Ајман Ал Завахири, иначе лекар по образовању. Ал Каида је у Авганистану формирала две примитивне лабораторије намењене производњи биолошког оружја. Међутим, брутална кампања САД и њених савезника након 11. септембра 2001. године онемогућила је даљи развој програма за биолошко оружје ове терористичке организације. Иако су амбиције Ал Каиде биле далеко изнад реалних капацитета неопходних за производњу и примену биолошког оружја, сама чињеница да се једна од најмоћнијих терористичких организација определила за нове моделе деловања и примену једног од оружја за масовно уништавање - било је крајње упозоравајуће не само за САД већ и глобалну безбедносну заједницу.

Напад антракс писмима из 2001. године спроведен је у недељама након напада Ал Каиде на мете у САД. Доказано је да је кроз поштански систем САД укупно послато 5 писама са спорама антракса високе чистоће. Смртно је страдало петоро људи, док је код 22 особе потврђена инфекција, а преко 30.000 грађана САД је било под

12 Gary Ackerman and Michelle Jacome, "WMD Terrorism-The Once and Future Threat". PRISM, Vol. 7, No. 3, 2018, p. 27. 
експонираним ризиком и превентивно је терапирано. Материјалне последице напада су се мериле милијардама долара утрошених на деконтаминацију простора и накнадно унапређење биолошке приправности САД. Након напада у једној од најдужих и најсложенијих истрага коју је Федерални истражни биро спровео у својој историји дошло се до потенцијалног извршиоца Бруса Ајвинса, експерта за антракс који је радио у војноистраживачкој лабораторији у америчком центру за биолошку одбрану у Форт Дитрику. Овај напад је квалификован као први акт биотероризма на територији САД, а који је за последицу имао људске жртве. Посматран у контексту претходног напада Ал Каиде, он је у великој мери изменио дотадашњи безбедносни амбијент и перцепцију биолошког оружја као потенцијалне претње. Такође, указао је на ризике који прате легитимни рад са опасним биолошким агенсима у смислу одсуства контраобавештајне и безбедносне заштите установа и људи у њима.

Исламска држава показала је не само мотивацију и жељу већ и конкретну опредељеност да у свој modus operandi уведе и примену биолошког оружја. Постоје материјални докази да је још 2014. године ова терористичка организација имала амбиције да произведе биолошко оружје. У конфискованом компјутеру припадника исламске државе из Туниса који је напустио сиријски град Идлиб пронађени су материјали и упутства која се односе на вепонизацију узрочника куге код људи ${ }^{13}$. Две године касније у Кенији је спречен биотерорисички напад који су планирали милитанти повезани са Исламском државом. При томе је као биолошки агенс одабран антракс14. Коначно, и најзначајнији пример посвећености Исламске државе ка примени биолошког оружја је из јуна 2018. године. Захваљујући врло темељном раду немачких обавештајних служби, у Келну је осујећен покушај примене биолошког оружја које се базирало на рицину15. Тунижанин Сиеф Алах (Sief Allah) je кроз бројне криптокомуникације са члановима Исламске државе са севера Африке добијао инструкције како да у импровизованим условима произведе рицин ${ }^{16}$, односно на који начин би могао да искористи експлозивну направу за његово дисперговање. Овај случај има посебно место у новијој безбедносној пракси, јер представља први пример успешне производње рицина на територији Запада од стране исламских џихадиста. Он уједно потврђује тезу да биотероризам више није фиктивна претња, већ и

13 Harald Doornbos and Jenan Moussa, „The Islamic State's Terror Laptop of Doom“. Foreign Policy, 28 ${ }^{\text {th }}$ August 2014, https://foreignpolicy.com/2014/08/28/found-the-islamic-statesterror-laptop-of-doom/, 17/08/2020.

14 Ty Mccormick, "Foiled Kenya Antrax Plot Hints at Islamic State's Scramble for Africa", Foreign Policy, 4th May 2016, https://foreignpolicy.com/2016/05/04/foiled-kenya-anthrax-plothints-at-islamic-states-scramble-for-africa, 01/07/2020; Alexander Smith, "Kenya Police Say They Foiled ISIS-Linked Plot to Unleash Anthrax Attack", NBC News, $4^{\text {th }}$ May 2016, https://www.nbcnews.com/news/world/kenya-police-say-they-foiled-isis-linked-plotunleash-anthrax-n567721, 18/08/2020.

15 Florian Flade, „The June 2018. Cologne Ricin Plot: A New threshold in Jihadi BioTerror“, CTC Sentinel, Vol. 11, No. 7, 2018, pp. 1-4.

16 Високотоксична материја произведена из семена биљке рицинусовог уља. 
реалност која у новим безбедносним околностима након ковида 19 добија посебан значај.

Екстремни десничарски покрети и њима блиски појединци већ годинама показују опсесивно интересовање ка оружју за масовно уништавање. У том смислу, значајно место има и биолошко оружје које сматрају погоднијим од нуклеарног, јер је доступно и одговара њиховим циљевима и оперативним капацитетима. У аналитичкој студији Келера и Попеле (Koehler D., Popella P.) из 2018. године проучавана је примена хемијског, биолошког, радиолошког и нуклеарног оружја (ХБРН) од стране радикалне деснице.17 У периоду 1970-2017. године они су регистровали укупно 31 инцидент у којима је примењено неко ХБРН средство. У идеолошком смислу, међу извршиоцима су доминирали неонацисти и бели супрематисти, а сваки трећи напад је био заснован на примени рицина.

\section{КОВИД 19 И БЕЗБЕДНОСНЕ ИМПЛИКАЦИЈЕ}

Реагујући на актуелну пандемију, генерални секрета УН А. Гутереш је 10. априла 2020. изјавио да „пандемија представља највећу претњу по одржавање међународног мира и безбедности, које ће довести до социјалних поремећаја и насиља, који ће озбиљно ослабити нашу способност да се боримо против болести“. Гутереш је такође упозорио да екстремистичке групе искоришћавају затварање друштва током борбе против ковида 19 да би ширили мржњу, као и интензивирали своје напоре и деловања путем друштвених медија у циљу регрутовања младих који сада проводе много више времена на интернету 18.

Ова последња тврдња нас је усмерила ка проучавању понашања терористичких организација, екстремистичких покрета и других потенцијално безбедносно интересантних актера у условима пандемије. Оно наиме може бити врло индикативно у смислу могућег предвиђања њиховог будућег деловања (након ковида 19), посебно у смислу евентуалног коришћења биолошког оружја.

Глобална примена бројних епидемиолошких мера усмерених ка спречавању ширења заразе у популацији, попут масовног смештања у карантин или редуковане социјалне динамике (затварање школа, обустављање јавног превоза, забране масовних окупљања на културним и спортским догађајима, затварање државних граница и др.), увела је читаво друштво у једну нову животну реалност која има пуну здравствену оправданост, али је донела и одређене безбедносне консеквенце. У овом контексту врло је занимљиво анализирати понашање

17 Daniel Koehler and Peter Popella, "Mapping Far Right Chemical, Biological,Radiological and Nuclear (CBRN) Terrorism Efforts in the West: Characteristics of Plots and Perpetrators for Future Threat Assessment", Terrorism and Political Violence, Published online 15th August 2018, pp. 1-25.

18 "COVID-19 threatening global peace and security, UN chief warns", UN News, $10^{\text {th }}$ April 2020, https://news.un.org/en/story/2020/04/1061502, 20/08/2020. 
најзначајнијих терористичких организација, односно припадника екстремних покрета који се сматрају значајним фактором угрожавања безбедности.

У врло актуелној анализи последица ковида 19 на понашање терориста коју је спровео британски професор Силк A. (Andrew Silk) са Универзитета Кранфилд (Cranfieold University), у сарадњи са компанијом Пул Pe (Pool Re, Terrorism reinsurance), представљени су краткорочни и дугорочни утицаји пандемије на тероризам у свету ${ }^{19}$. Краткорочно гледано, увођењем епидемиолошких мера којима се ограничавају кретања људи уз социјално дистанцирање, објективно се мења и амбијент оперативног деловања терориста. Општа стопа криминалитета у Великој Британији је опала, а активне терористичке и радикализоване екстремистичке групе су принуђене да се притаје и раде „у кућним условима“, што је преусмерило њихове активности ка интернету и мобилним платформама. Уједно, грађани су били приморани да више времена проводе код куће уз повећану експонираност потенцијалним пропагандним садржајима на интернету. У тим околностима интензивирано је деловање исламских и десничарских група усмерених ка индоктринацији и радикализацији појединаца, регрутовању новог чланства, пропагандног промовисања различитих теорија завера које прате ковид 19 и сл.

У својој анализи утицаја ковида 19 на глобални џихадизам и прилагођавања новим околностима јордански писац и истраживач Хасан Аби Ханејех (Hassan Aby Naheyeh) је направио поређење између Ал Каиде и Исламске државе. По Ханејеху, „Исламска држава је показала супериорност у односу на Ал Каиду, и то кроз теоријске и практичне нивое деловања“20. Наиме, поруке Ал Каиде својим члановима су махом имале идеолошку и пропагандну оријентацију и указивале су на ковид 19 као „божју казну за невернике“, при чему их није позивала на вршење терористичких активности. Исламска држава је са друге стране показала много бољу прилагодљивост на нове околности. Прве поруке које је Исламска држава упућивала својим члановима и симпатизерима се односила на строго придржавање неопходних мера за личну заштиту од CAPC-КоВ-221. Већ у следећем издању свог пропагандног онлајн недељника Ал Набаа, Исламска држава описује пандемију као „крсташку ноћну мору“ и позива на искоришћавање читаве ситуације око пандемије за остваривање својих циљева ${ }^{22}$. Тако она позива своје чланство на проактивно деловање у два смера: интензивирање напада на непријатеље и ослобађање својих сабораца из затвора у Ираку и Сирији. Ове

19 Andrew, Silke, "Covid-19 and terrorism: assessing the short and long term impacts", Pool Re, $5^{\text {th }}$ May 2020, https://www.poolre.co.uk/solutions/risk-awareness/covid-19-and-terrorismreport/, 21/08/2020.

20 Hassan Abu Haneyeh, „How COVID-19 Facilitated the Rebirts of Global Jihadism“, Pulitzer Center, 3rd June 2020. https://pulitzercenter.org/reporting/how-covid-19-facilitatedrebirth-global-jihadism, 16/06/2020.

21 Избегавање места на којима је присутна зараза, покривање лица приликом кашљања и кијања, прање руку и сл. Al Nabaa 225 12. Март 2020.

22 Al Nabaa 226, 20. mart 2020. 
поруке су касније имале одјек међу борцима Исламске државе који су спроводили нападе на војне и друге непријатељске циљеве у Ираку. Међутим, за потпуније разумевање утицаја овида 19 на безбедносни амбијент на простору Блиског истока, посебно Ирака, врло је битно указати и на понашање међународне заједнице која је, може се рећи, постала пасивна и која је на одређени начин одустала од даљег ангажовања у супротстављању Исламској држави. Прво је у марту суспендован рад Центра за обуку међународних снага и НАТО, да би убрзо након тога своје инструкторе из склопа међународних снага повукле Аустралија, Шпанија, Француска и Велика Британија. ${ }^{23}$

У овом контексту је занимљива анализа коју дају Онг и Азман (Kyler Ong, Nur Aziemah Azman), указујући на разлике између Исламске државе са једне стране и екстремне деснице у односу на могуће искоришћавање ковида 19 у свом деловањ ${ }^{24}$. Једна од основних разлика је у позиву десничарских организација да се вепонизује узрочник пандемије САРC-КоВ-2 и да се кроз више модела адаптације примењује према својим традиционалним метама (тамнопути грађани, Јевреји, полиција, муслимани и др). Примитивна вепонизација САРС-КоВ2 је подразумевала прикупљање спутума оболелих припадника организације и просто распршивање по јавним површинама, рукохватима у синагогама или директно кашљање у лице према особама које су препознате као мете напада. Иако Исламска држава није без искустава у намерама да примени биолошко оружје, она ипак није тежила мотивацији и подстрекивању својих бораца и симпатизера ка овом виду експлоатације SARS-CoV-2 вируса.

y антиципацији могућих терористичких деловања током и након пандемије поменута аналитичка студија професора Силка је закључила да је за терористе у условима активне пандемије јавност у стању својеврсне десензибилизације према сваком даљем угрожавању јавног здравља. Отуда је за терористе афирмативније да своје активности одложе за период након пандемије. Овај став је образложен значајем медијске пажње и публицитета који прати сваку терористичку активност. У условима активне пандемије тај ефекат евентуалног напада би имао мању медијску атрактивност и утицај на јавност 25.

23 Hassan Abu Haneyeh, „How COVID-19 Facilitated the Rebirts of Global Jihadism“, op. cit.

24 Kyler Ong and Nur Aziemah Azman, "Distinguishing Between the Extreme Farright and Islamic State's (IS) Calls to Exploit COVID-19", Counter Terrorist Trends and Analyses, Vol. 12, No. 3,2020, pp. 20.-21.

25 Andrew Silke, "Covid-19 and terrorism: assessing the short and long term impacts", op. cit., p. 6. 


\section{НОВА БЕЗБЕДНОСНА РЕАЛНОСТ НАКОН КОВИДА 19 И ЗНАЧАЈ БИОТЕРОРИЗМА}

Циљана примена биолошког оружја од стране терористичких организација, екстремних десничарских група или радикализованих појединаца у новим безбедносним околностима након ковида 19 не представља имагинарни сценарио, већ једну реалну могућност. Међутим, препреке у стицању биолошког агенса и његовом трансформисању у биолошко оружје и даље представљају изазове који делују лимитирајуће у смислу планирања напада великог обима и интензитета који би могао да изазова тешке поремећаје здравља великог броја људи. Иако се оперативни капацитети поменутих актера безбедносног угрожавања развијају и осавремењују, тешко је веровати да иједна организација може самостално произвести биолошко оружје разорне моћи. Реалније је да говоримо о мањим количинама биолошких токсина или одређених бактерија које се могу употребити за деловање на појединачне мете (атентати) или на мањи број људи у одређеном простору (биотерористички напади мањег обима). Изузетак из ових хипотетичких пројекција представљају ситуације у којима се појављује синергија државног субјекта и неке малициозне организације. Стављање националних ресурса из домена биотехнологије или молекуларне генетике у функцију деловања било које терористичке организације се сматра једним од најопаснијих видова злоупотребе биолошког оружја који би могао имати последице апокалиптичних размера по човечанство. На крају не би смели игнорисати и ризик од радикализованих појединаца у типу „усамљених вукова“, који могу припадати било ком сегменту идеолошког спектра. За обавештајнобезбедносну заједницу они представљају субјекте угрожавања према којима је најтеже деловати превентивно и дефанзивно. Случај антраксних писама из 2001. године најбоље илуструје потенцијалне последице једног оваквог напада. Уједно нас подсећа на значај поштовања и примене стандарда биолошке сигурности и безбедности у институцијама које се баве истраживањем и легитимним применама опасних микроорганизама (нпр. у производњи вакцина и сл).

Када размишљамо о могућим корисницима биолошког оружја у будућности, занимљиву тезу је изнео професор Силк у оквиру поменуте аналитичке студије о утицајима ковида 19 на тероризам. Наиме, он указује да нас историјска искуства у биотероризму уче како је биолошко оружје обично било у плановима деловања религиозно мотивисаног или десничарског тероризма, што је забрињавајуће ако се зна да говоримо о покретима који тренутно егзистирају у многим државама. Отуда је разумљива претпоставка да у перспективи биолошко оружје може представљати реалну претњу угрожавања од стране џихадиста попут Исламске државе или различитих екстремних организација десне оријентације. 


\section{ПРЕВЕНЦИЈА БИОТЕРОРИЗМА И СУПРОТСТАВЉАЬЕ БИОТЕРОРИЗМУ}

Већ смо поменули да је пандемија једна од најтежих могућих последица биотероризма. У том смислу указали бисмо на чињеницу да је пандемија као безбедносна претња присутна у различитим стратешким актима многих најразвијенијих земаља света. Кинески председник Си Ђинпинг је 2017. године на 19. Националном конгресу Комунистичке партије Кине указао на потенцијалну опасност од пандемије 26 . Такође, актуелна администрација САД је у Стратегији националне безбедности из 2017. године сврстала биолошке претње и пандемију као приоритетне безбедносне претње по САД27. Велика Британија је још 2008. године пандемију грипа препознала као безбедносни ризик и претњу по националну безбедност ${ }^{28}$.

Република Србија такође поседује стратешкодоктринарна документа у којима се пандемија сматра претњом по националну безбедност. ${ }^{29}$ Имајући све ово у виду, с разлогом се поставља питање: ко је онда заказао у случају ковида 19? Здравствени систем, безбедносни сектор, комплетни државни апарат или недостатак јединственог међународног одговора на глобалну кризу? У годинама након ковида 19 биће неопходно ревидирати постојеће безбедносне доктрине које не препознају значај пандемија (независно од њене генезе) као безбедносног питања, али и детаљно разрадити примењиве моделе деловања различитих ентитета у оквирима националних безбедносно-обавештајни система.

У домену превенције биотероризма занимљиво запажање су изнели Келер и Попела (Koehler D, Popella P), наглашавајући значај ране детекције активности биотерориста у фази осмишљавања и припреме напада. Они посебно акцентују једну особину екстремистичких десничарских група, које у коришћењу полузатворених или криптованих канала комуникације често не скривају своје намере и амбиције. По томе се суштински разликују од верског екстремизма и радикалних исламских организација, чија је комуникација неупоредиво затворенија. То отвара простор обавештајно- безбедносном сектору да лакше превенира њихове потенцијалне нападе ${ }^{30}$.

26 Xi Jinping, "Secure a Decisive Victory in Building a Moderately Prosperous Society in All Respects and Strive for the Great Success of Socialism with Chinese Characteristics for a New Era", 19th National Congress of the Communist Party of China, Beijing, $18^{\text {th }}$ October, 2017.

27 "National Security Strategy of the United State of America (2017)", White House, Washington, December 2017, pp. 8-9.

28 "National Risk Register (2008)" Cabinet Office (UK), London, 2008, https://assets.publishing.service.gov.uk/government/uploads/system/uploads/attachment_ data/file/61934/national_risk_register.pdf, 11/08/2020.

29 „Стратегија националне безбедности Републике Србије (2019)“, Службени гласник РС, бр. 94/2019, Београд, 27. децембар 2019.

30 Daniel Koehler and Peter Popella, "Beware of CBRN Terrorism - From the Far-Right", Small Wars Journal 19th September 2017,

https://smallwarsjournal.com/jrnl/art/beware-of-cbrn-terrorism-from-the-far-right, $07 / 07 / 2020$. 


\section{ЗНАЧАЈ МЕЪУНАРОДНЕ САРАДЊЕ У СУПРОТСТАВЉАЊУ БИОТЕРОРИЗМУ}

Једно од можда и најзначајнијих искустава и порука за међународну заједницу када говоримо о ковиду 19 јесте неминовност заједничког деловања и успостављања регионалних, па и глобалних модела сарадње у превенирању, спречавању ширења и отклањању последица пандемије.

Посебан проблем у раним фазама супротстављања ковиду 19 било је евидентно одсуство међународне кооперативности и сарадње, али и губитак поверења у Светску здравствену организацију (С30), као кровну институцију од есенцијалног значаја у глобалном координисаном одговору ка пандемију. Такође, врло је индикативно и понашање појединих чланица ЕУ, односно НАТО савеза, када говоримо о облицима међународне сарадње и солидарности у условима глобалне кризе каква је она изазвана ковидом 19.

Време после ковида ће свакако захтевати да се кроз постојеће, али и нове моделе међународног повезивања и сарадње успостави систем боље и ефикасније борбе против биотероризма. Комитет за противтероризам Савета Европе (The Council of Europe Committee on Counterterrorism, CDCT) је још у јеку пандемије реаговао, указујући на слабости савремених друштава према пандемији, упозоравајући да би глобално ширење САРС-КоВ-2 вируса могло да повећа ризике од могуће примене биолошког оружја од стране терориста. Надаље, ово тело ЕУ напомиње да је неопходно да се свих 47 земаља чланица посвете обуци и припремама за потенцијални терористички напад биолошким оружјем ${ }^{31}$.

\section{РИЗИК ОД БИОТЕРОРИЗМА У РЕПУБЛИЦИ СРБИЈИ}

Постављање Србије у контекст потенцијалног ризика од биотерористичког угрожавања након ковида 19 није алармантно, али се не би смело игнорисати. Мишљења смо да, с обзиром на досадашња безбедносна искуства, Србија не представља простор у којем би исламски терористи тражили потенцијалне мете деловања, али је сасвим извесно да постоје фактори који у ширем контексту могу допринети планирању или спровођењу биотерористичких напада, првенствено на територији држава Запада. У том смислу, указујемо на значај постојећих миграторних кретања кроз Србију, односно на утицај повратника са ратишта са простора деловања Исламске државе.

Миграциони токови представљају јединствен канал за дисперзију људи међу којима можда има и оних који поседују одређену стручност, искуство или практичну рутину у пословима који су повезани са производњом биолошког

31 "The Council of Europe continues working to enhance international co-operation against terrorism, including bioterrorism", Council of Europe Portal, 25 $5^{\text {th }}$ May 2020, https://www.coe.int/en/web/counter-terrorism/-/covid-19-pandemic-the-secretariat-ofthe-committee-on-counter-terrorism-warns-against-the-risk-of-bioterrorism, 07/07/2020. 
оружја ${ }^{32}$. Ова претпоставка додатно добија на значају ако се зна да су Сирија, а посебно Ирак, земље које су у својој војној индустрији имали развијене погоне за биолошко оружје. Такође, и повратници из ратом захваћених подручја у којима делује Исламска држава доносе одређени ризик од биотероризма. Већ је поменуто да је Исламска држава од 2014. године радила на примитивној вепонизацији и примени узрочника куге, рицина и антракса према својим непријатељима.

На крају, када говоримо о Србији и ризику од биотероризма, мора се указати и на јаке традиционалне везе њене екстремне деснице са сродним покретима широм Европе. Да то нису само пропагандно-идеолошке кореспонденције, говори и пример из 2009. године. Припадници британске екстремне десничарске организације Аријевска ударна снага (Aryan Striкe Force, ASF) успели су у импровизованим условима да произведу малу количини рицина, која је у зависности од начина примене била довољна да усмрти неколико хиљада људиз3. Међутим, оно што овај случај повезује са Србијом су планови британских екстремиста да произведени отров у сарадњи са „српским колегама“ примене на територији Србије. Наиме, током истраге је утврђено да је постојала идеја да се рицин пребаци у Србију, где би се искористио за контаминацију система за водоснабдевање у муслиманским местима 34 . Овај напад је благовремено осујећен од стране британских служби и представљао је први правно процесуирани случај тероризма заснованог на оружју за масовно уништавање у Великој Британији. Сем тога, значајно је поменути и да је најпознатији припадник радикалне деснице Андерс Брејвик у свом чувеном Манифесту на више места наводио Србију и чланове њених десничарских организација 35 . Чак је у одељку Манифеста који се односи на биолошко оружје навео да је „прибављање оружја за масовно уништавање од српских националиста један реалан сценарио“. С обзиром на актуелни Брејвиков статус идола међу екстремним десничарима широм света, ове чињенице могу представљати солидне индикаторе у будућем безбедносном сагледавању сродних идеолошких покрета и појединаца на територији Србије, посебно у домену израде и примене, не само биолошког оружја, већ и других неконвенционалних средстава деловања.

32 Brian Dodwell, Daniel Milton, and Don Rassler, The Caliphate's Global Workforce: An inside Look at the Islamic State's Foreign Fighter Paper Trail, United States Military Academy, West Point, April, 2016.

33 Martin Wainwright, „Neo-Nazi Ian Davidson jailed for 10 years for making chemical weapon“, The Guardian, 14th May 2010,

https://www.theguardian.com/uk/2010/may/14/neo-nazi-ian-davison-jailed-chemicalweapon, 01/08/2020.

34 Daniel Koehler and Peter Popella, "Beware of CBRN Terrorism - From the Far-Right", Small Wars Journal 19 $9^{\text {th }}$ September 2017,

https://smallwarsjournal.com/jrnl/art/beware-of-cbrn-terrorism-from-the-far-right, 07/07/2020.

35 Anders Breivik, 2083: A European Declaration of Independence, London, 2011, https://info.publicintelligence.net/AndersBehringBreivikManifesto.pdf, 15/08/2020. 


\section{ЗАКЉУЧАК}

Независно од тога о којој терористичкој организацији, групи или покрету говоримо, свакако можемо рећи да је актуелна пандемија ковида 19 на крајње експлицитан начин указала на неколико чињеница које у значајном мери могу утицати на стратешке и оперативне моделе њиховог деловања у будућности. Прво, савремена друштва су се показала неспремним не само у медицинском већ и у безбедносном смислу према овој врсти нетипичне безбедносне претње. Поред тога, током пандемије примећена је усредсређеност држава на здравствена питања, програм мера за излазак из економске и политичке кризе, чиме се преусмеравају и троше бројни ресурси на активности које се не баве класичним безбедносним питањима, попут борбе против организованог криминала или тероризма. Реално је претпоставити да се повратак у стање пре ковида 19 неће десити са окончањем пандемије. У том смислу, рањивост држава може сама по себи додатно деловати мотивационо по терористе. Ова пандемија заправо у пуном капацитету промовише нове потенцијалне обрасце терористичког деловања, и то као путоказ и инспирација. У њима је реафирмисана примена биолошких средстава деловања, и то првенствено од стране џихадистичких покрета (Исламске државе са припадајућим афилијацијама у свету), радикалних десничарских организација и појединаца - усамљених вукова. Њихова опредељеност ка биолошком оружју и растући оперативни капацитети, уз све доступније примене савремених технологија, приближавају их нивоу на којем ће моћи да произведу и примене биолошко оружје. Извесно је да се након ковида 19 биотероризам из једног апстрактног простора сели у безбедносну реалност која може постати врло упозоравајућа и све извеснија.

\section{ЛИТЕРАТУРА}

- "COVID-19 threatening global peace and security, UN chief warns", UN News, 10th April 2020, https://news.un.org/en/story/2020/04/1061502, 20/08/2020.

- "National Risk Register (2008)" Cabinet Office (UK), London, 2008, https://assets.publishing.service.gov.uk/government/uploads/system/uploads/attac hment_data/file/61934/national_risk_register.pdf, 11/08/2020.

- "National Security Strategy of the United State of America (2017)“, White House, Washington, December 2017.

- "The Council of Europe continues working to enhance international co-operation against terrorism, including bioterrorism", Council of Europe Portal, 25th May 2020, https://www.coe.int/en/web/counter-terrorism/-/covid-19-pandemic-thesecretariat-of-the-committee-on-counter-terrorism-warns-against-the-risk-ofbioterrorism, 07/07/2020.

- „Стратегија националне безбедности Републике Србије (2019)“, Службени гласник РС, бр. 94/2019, Београд, 27. децембар 2019. 
- Abu Haneyeh, Hassan. „How COVID-19 Facilitated the Rebirts of Global Jihadism“, Pulitzer Center, 3rd June 2020. https://pulitzercenter.org/reporting/how-covid-19facilitated-rebirth-global-jihadism,

- Al Nabaa 226, 20. март 2020.

- Al Nabaa 225 12. март 2020.

- Andrew, Silke; "Covid-19 and terrorism: assessing the short and long term impacts", Pool Re, 5th May 2020, https://www.poolre.co.uk/solutions/risk-awareness/covid19-and-terrorism-report/.

- Breivik, Anders. 2083: A European Declaration of Independence, London, 2011, https://info.publicintelligence.net/AndersBehringBreivikManifesto.pdf,

- Carus, W. Seth. Bioterrorism and Biocrimes: The Ilicit Use of Biological Agents Since 1990, National Defence University Washington, D.C., 2001,

- Clark, William. „Is the Threat of Bioterrorism Exaggerated?", Home Land Security News, 23rd May 2008, http://www.homelandsecuritynewswire.com/threatbioterrorism-exaggerated.

- Clark, William. Bracing for Armagedon-The Science and Politics of Bioterrorism in America, Oxford University Press, Oxford, 2008.

- Dodwell, Brian, Milton, Daniel, and Rassler, Don. The Caliphate's Global Workforce: An inside Look at the Islamic State's Foreign Fighter Paper Trail, United States Military Academy, West Point, April, 2016.

- Doornbos, Harald and Moussa, Jenan. „The Islamic State's Terror Laptop of Doom“. Foreign Policy, 28th August 2014, https://foreignpolicy.com/2014/08/28/found-theislamic-states-terror-laptop-of-doom/.

- Eisenstadt, Michael. Iranian Military Power: Capabilities and Intentions. The Washington Institute for Near East Policy, Washington D.C., 1996.

- Flade, Florian. „The June 2018. Cologne Ricin Plot: A New threshold in Jihadi BioTerror", CTC Sentinel, Vol. 11, No. 7, 2018, pp. 1-4.

- Gary Ackerman and Michelle Jacome, "WMD Terrorism-The Once and Future Threat". PRISM, Vol. 7, No. 3, 2018, pp. 23-36.

- IRNA, 19 October 1998; FBIS Document, FBIS-NES, 19. October 1998;

- Jinping, Xi. "Secure a Decisive Victory in Building a Moderately Prosperous Society in All Respects and Strive for the Great Success of Socialism with Chinese Characteristics for a New Era", 19th National Congress of the Communist Party of China, Beijing, 18th October, 2017.

- Koehler, Daniel and Popella, Peter. "Mapping Far Right Chemical, Biological,Radiological and Nuclear (CBRN) Terrorism Efforts in the West: Characteristics of Plots and Perpetrators for Future Threat Assessment", Terrorism and Political Violence, Published online 15th August 2018, pp. 1-25.

- Koehler, Daniel and Popella, Peter. "Beware of CBRN Terrorism - From the Far-Right", Small Wars Journal 19th September 2017, https://smallwarsjournal.com/jrnl/art/beware-of-cbrn-terrorism-from-the-far-right. 
- Leitenberg, Milton, Assesing the Biological Weapons and Bioterrorism Threat, Strategic Studies Institute, Carlisle, 2005.

- Leitenberg, Milton. „Bioterrorism Hyped“; LA Times, 17th February 2006, https://www.latimes.com/archives/la-xpm-2006-feb-17-oe-leitenberg17-story.html.

- Mccormick, Ty. "Foiled Kenya Antrax Plot Hints at Islamic State's Scramble for Africa", Foreign Policy, 4th May 2016, https://foreignpolicy.com/2016/05/04/foiled-kenyaanthrax-plot-hints-at-islamic-states-scramble-for-africa, 01/07/2020;

- Ong, Kyler and Azman, Nur Aziemah. "Distinguishing Between the Extreme Farright and Islamic State's (IS) Calls to Exploit COVID-19", Counter Terrorist Trends and Analyses, Vol. 12, No. 3,2020, pp. 18-21.

- Paula Desutter, Denial and Jeopardy: Deterring Iranian Use of NBC Weapons, National Defense University, Washington D.C., 1997.

- Schmidt Alex. The Routledge Handbook of Terrorism Research. Routledge, London and New York, 2011.

- Simon Jeffrey. Terrorist and Potential Use of Biological Weapons, A discussion of Possibilities. RAND Corporation, Santa Monica, 1989.

- Smith, Alexander. "Kenya Police Say They Foiled ISIS-Linked Plot to Unleash Anthrax Attack", NBC News, 4th May 2016, https://www.nbcnews.com/news/world/kenyapolice-say-they-foiled-isis-linked-plot-unleash-anthrax-n567721.

- Voorhaar, Heather. Antibody Architecture: Responding to Bioterrorism, Master Thesis, Clemnson University, Advisor David Allison, 2009.

- Wainwright, Martin. „Neo-Nazi Ian Davidson jailed for 10 years for making chemical weapon", The Guardian, 14th May 2010, https://www.theguardian.com/uk/2010/may/14/neo-nazi-ian-davison-jailedchemical-weapon, 01/08/2020.

\section{BIOTERRORISM AS A SECURITY THREAT FOLLOWING COVID-19: OLD MYTHS OR THE NEW TRUTH}

Abstract: The basic idea of this paper is to come to conclusions through the analysis of the current Kovid-19 pandemic, as well as previous experiences of certain countries in the field of countering bioterrorism, about new possible forms of its manifestation and misuse of biological agents in terrorist acts. Namely, through the review of the activities of Al Qaeda and the Japanese sect Aum Shinrikyo and the case study of anthrax letters in the USA from 2001, the key experiences and obstacles in the procurement, development and application of biological weapons were pointed out. In addition, key newly gained experiences and lessons from the Kovid-19 pandemic in the field of public health, efficiency of health systems and global security were presented. At the same time, potential future users of biological weapons are profiled, as well as possible methods of application or targets. Finally, the responsibility of the professional and academic community dealing with the 
study of bioterrorism was emphasized, based on the previous tendencies of societies and decision makers to exaggerate or underestimate the security significance of bioterrorism and its possible consequences. It is in this wide space of security assessments, from the apocalyptic scale in human casualties to ignoring risks and possible consequences, Kovid-19 provides us with very valuable experiences in objectifying and correctly perceiving some future manifestation of bioterrorism as a security threat.

Key words: COVID-19, bioterrorism, pandemic, SARS-KoV-2, Al Qaeda, Aum Shinrikyo 